\title{
Electrical Stimulation in the Bone Repair of Defects Created in Rabbit Skulls
}

\author{
Estimulación Eléctrica en la Reparación Ósea de Defectos Creados en Cráneos de Conejos
}

\author{
C. Silva*; S. Olate**; L. Pozzer*; M. Muñoz ${ }^{* * * * * * * ;}$; M. Cantín ${ }^{* * * * *}$; F. Uribe ${ }^{* *, * * * * * *}$ \& J. R. de Albergaría-Barbosa*
}

SILVA, C.; OLATE, S.; POZZER, L.; MUÑOZ, M.; CANTÍN, M.; URIBE, F. \& DE ALBERGARIA-BARBOSA, J. R. Electrical stimulation in the bone repair of defects created in rabbit skulls. Int. J. Morphol., 33(3):1146-1150, 2015.

SUMMARY: Electrical stimulation has been used in different conditions for tissue regeneration. The aim of this study was to analyze the tissue response of defects created in rabbit skulls to electrical stimulation. Two groups were formed, each with 9 New Zealand rabbits; two $5 \mathrm{~mm}$ defects were made, one in each parietal, with one being randomly filled with autogenous bone extracted as particles and the other maintained only with blood clotting. The rabbits were euthanized at 8 weeks and 15 weeks to then study the samples collected histologically. In the 8-week analysis bone formation was observed in the defects in the test and control filled with bone graft, whereas the defects with clotting presented a very early stage of bone formation with abundant connective tissue. At 15 weeks an advanced stage of bone regeneration was identified in the defects with bone graft, whereas no significant differences were found in the electrically stimulated defects. In conclusion, electrical stimulus does not alter the sequence of bone formation; new studies could help establish patterns and influences of the stimulus on bone regeneration.

KEY WORDS: Electrical stimulus; Bone regeneration; Bone graft.

\section{INTRODUCTION}

Bone grafts are widely used for the reconstruction of atrophic alveolar ridges. Autogenous bone and replacement bones have been analyzed in different scenarios, yielding results that vary based on different research models and characteristics of the bone defects.

Thus, it has been determined that particle size is a factor in bone regeneration capacity (Klüppel et al., 2013) and that the vascularization properties of the recipient bed might also be relevant in bone integration (de Oliveira et al., 2013). The types of materials used as well as their agents of application are also factors that may permit enhanced adaptation and bone integration of the defect (Duque Netto et al., 2013). Within this wide network of factors that might influence tissue regeneration capacity, the continuous autogenous graft is the gold standard in bone integration (Olate et al., 2007), such that its use as a control in different studies is an important element.
Being aware of the biological processes present in bone regeneration, the use of different technologies could improve conditions for integration. The application of electrical stimuli has been used frequently in neurosurgery, obtaining satisfactory results in terms of bone regeneration (Oishi \& Onesti, 2000). In oral and maxillofacial surgery, however, there is limited information; recent studies by our group (Buzzá et al., 2014) showed that there were no significant differences between the groups with application of electrical therapy and the groups without electrical therapy in implant-associated defects, whereas Kaynak et al. (2005) reported a significant relation in periodontal regeneration related to electric therapy.

The aim of this study was to identify the bone repair model in defects created in rabbit skulls using electrical stimulation.

\footnotetext{
Division of Oral and Maxillofacial Surgery, State University of Campinas, Campinas, Brazil.

** Division of Oral and Maxillofacial Surgery, Universidad de La Frontera, Temuco, Chile.

*** Center for Biomedical Research, Universidad Autónoma de Chile, Temuco, Chile.

***** Universidad Científica del Sur, Lima, Perú.

****** PhD Program in Morphology, Universidad de La Frontera, Temuco, Chile.

******* PhD Program in Medical Sciences, Universidad de La Frontera, Temuco, Chile.
} 


\section{MATERIAL AND METHOD}

Eighteen male albino New Zealand rabbits were used, with an average weight of $3.0 \mathrm{~kg}$ and aged between 3 and 6 months. All the animals were kept on a diet of solid food and water ad libitum.

Surgery. The anesthesia used was 2 (2,6-xylidine) - 5,6dihydro- $4 \mathrm{H}-1,3$ thiazine hydrochloride in a dose of $2 \mathrm{mg} / \mathrm{kg}$ of body weight combined with ketamine hydrochloride in a dose of $10 \mathrm{mg} / \mathrm{kg}$; atropine sulfate $(0.05 \mathrm{mg} / \mathrm{kg})$ was also used to reduce intraoperative respiratory risks.

After carrying out a trichotomy on the calvarium of the animal and using aseptic and antiseptic techniques with chlorhexidine $0.5 \%$, the surgical area was isolated with sterile fields typical of these procedures.

A mid-line incision was made in the calvarium, extending between the frontal and occipital bone; the periosteum of the zone was completely separated. The osteotomies were performed using $5 \mathrm{~mm}$ trephines, making two holes in each side of the skull, taking care not to perforate the dura mater. The osteotomies were done with a low-speed motor and constant irrigation with saline.

One side was randomly selected to be maintained without any type of filling; the other side was filled with the bone extracted from both sectors and used in particle form. Plane sutures were used as per normal protocols. Under these conditions four groups were created: Group 1 was the control and Group 2 the experimental. Intraoperative and postoperative antibiotic and analgesic therapy was administered regularly to all the animals.

Electrical stimulation. Forty-eight hours after the surgery, electrical stimulation was applied to the experimental group, for which a box was designed where the body was kept (horizontally) to ensure the fixed position of the animal, keeping the head exposed outside the box. A device fixed with elastics was installed on the animal's skull, which contained the electrodes that came in contact with the skull, with the orbital and maxillomandibular area free of any fixation.

The Healtec Celular system (Healtec Electromedicina Ltda.) was used with frequencies from 20 to $350 \mathrm{MgHz}$, spaces of $1 \mathrm{MgHz}$, impulses of 85 microseconds and adjustable pauses in $80,160,320$ and 640 cycles; the monitored outputs had a depth of action of $25 \mathrm{~cm}$ and power of 1 to $4.5 \mathrm{~W}$. The animals received 160 cycles for 1 hour a day for 21 days ( 3 weeks).
The animals were euthanized at 8 and 15 weeks (4 and 5 animals at each stage) from the initial surgery, for which an overdose of anesthetic was applied.

Histology. Samples were obtained using sections of the skull made with a saw and drill-bits, staying at least $1 \mathrm{~cm}$ from the edge of the defect created. The samples were kept in buffered formalin for $24 \mathrm{~h}$ to be decalcified later with $0.5 \%$ nitric acid for 20 days. Next, the pieces were subjected to diaphanization and slides were prepared with routine techniques using $6 \mathrm{~mm}$ serial sections and H\&E staining for study under an optical microscope.

\section{RESULTS}

The study was without complications and free of any other alterations in the operating protocol.

\section{8-week period}

Control group. Non-grafted defect: The hole within the defined bone and the presence of connective tissue were identified; islands of bone tissue were observed in the central portion at the initial stages of formation.

Grafted defect: The graft component had vascularization and the presence of medullary bone tissue. The process was at an advanced stage, although some necrotic elements were observed. There was a large amount of connective tissue.

Experimental group. Non-grafted defect: Considerable areas of connective tissue were found in the hole; in the center of the defect there were centers of calcification surrounded by fibrous connective tissue and with limited vascularity.

Grafted defect: The border between the pre-existing bone and the graft had a high level of vascularization and an advanced stage of organization; the graft appeared to be incorporated with the formation of two corticals. In some sections, small areas of necrotic bone were observed, with a good expression of the reparation tissue predominating.

\section{5-week period}

Control group. Non-grafted defect: Defined limits were observed between the pre-existing bone and the defect created with a large amount of fibrous connective tissue; greater vascularization was observed than at the previous stage, showing a defined medullary tissue together with adipose tissue. 
Grafted defect: The edge of the defect was difficult to define due to the presence of newly formed bone tissue with an adequate level of maturation. There was still fibrous connective tissue in a smaller amount; the newly formed bone tissue was of good quality and with an adequate number of cells involved.

Experimental group. Non-grafted defect (Fig. 1): A significant amount of newly formed bone tissue was observed with two well-defined corticals and fibrous tissue remnants; there was adequate vascularization between the edge of the defect and the newly formed tissue.

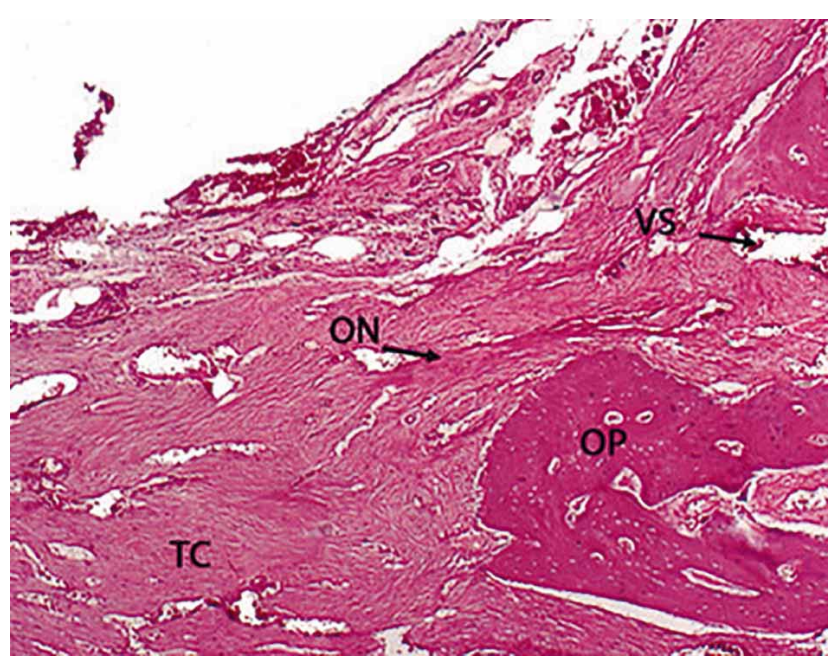

Fig. 1. Histological image of bone repair in the graft with filling after 15 weeks in the control group ( $\mathrm{NB}=$ new bone, $\mathrm{PB}=$ previously present bone, $\mathrm{CT}=$ connective tissue, $\mathrm{BV}=$ blood vessel).

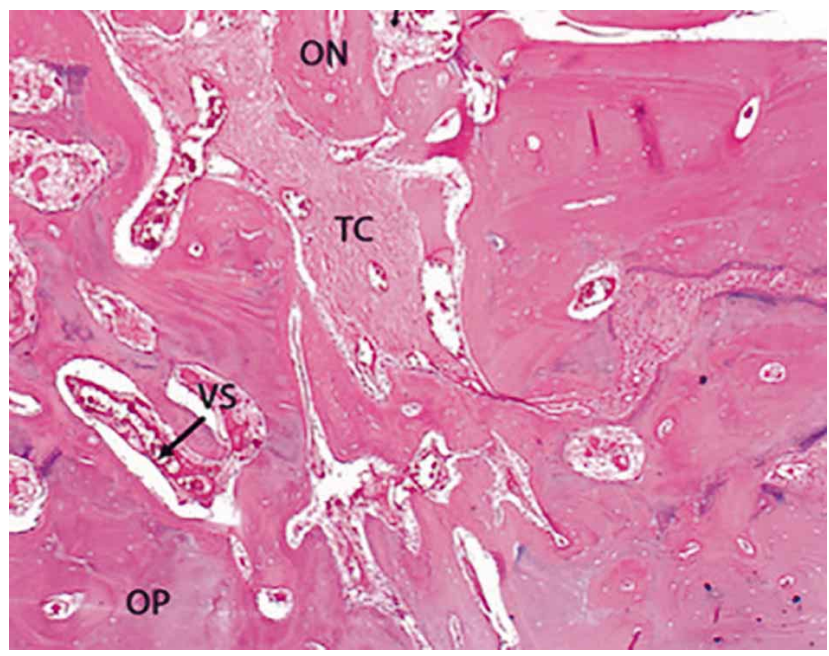

Fig. 2. Histological image (10X) of the bone graft defect from the test group (with application of electrical stimulus) $(\mathrm{NB}=$ new bone, $\mathrm{PB}=$ previously present bone, $\mathrm{CT}=$ connective tissue, $\mathrm{BV}=$ blood vessel).
Grafted defect (Fig. 2): No differences were observed between the newly formed bone in the defect and the preexisting bone; two well-defined corticals were observed in the upper and lower area that integrated with the bone surrounding the bone defect.

\section{DISCUSSION}

Bone reconstruction with the aim of achieving functional loading through dental implants has been analyzed in multiple studies. A range of non-autogenous materials have been used with varying success (de Oliveira et al., 2014; Duque Netto et al.), providing important information in terms of tissue regeneration.

The biological and mechanical conditions observed in alveolar defects are varied, so that the analysis performed on an animal model can give valuable information for these analyses. Al-Nawas \& Schiegnitz (2014) conducted a metaanalysis, comparing several bone substitutes with autogenous grafts, and reported that there were no differences in the implant survival comparing the two materials; nevertheless, a limitation in the clinical application of these results is indicated in the size of the defect and the volume and real regeneration capacity from the materials used. This limitation makes sense, where some studies have reported that the biological capacity of the recipient, vascularization of the zone and bone quality of the recipient bed would have an important role in bone regeneration (de Oliveira et al., 2013).

Although some bone substitutes have demonstrated adequate versatility, the continuous autogenous bone graft was the only one able to reach regeneration based on the three principles of osteogenesis, osteoinduction and osteoconduction (Olate et al.; Netto et al., 2013). Thus, when new elements are applied to the regenerative process the gold standard is needed to then analyze other types of materials.

In neurosurgery, the electrical application for osteogenesis has a well-documented history (Oishi \& Onesti); however, it has not had a significant impact on oral and maxillofacial surgery. The model applied in this study has been published previously with the use of dental implants (Buzzá et al.), concluding the absence of significant differences in bone regeneration with or without the application of electrical stimuli. Kaynak et al. studied the electrical effect on periodontal regeneration in a canine model, obtaining favorable and significant results at the sites where electrical potential was applied as therapy. In a systematic review on bone regeneration for spinal fusion 
they showed that any of the protocols validated on electrical stimulation resulted in arthrodesis formation, although limited relevant studies had been conducted to examine this condition (Tian et al., 2013).

The number of samples in the study limited the possibility of statistical development between the groups; however, the bone formation model was similar in the two groups. The autogenous bone graft group with electrical stimulation presented a more advanced stage of bone regeneration, indicating a possible positive response. Nevertheless, considering the analysis times for euthanasia, the differences were mainly in the 15 -week group, coinciding in that the control group also presented an advanced stage of bone regeneration.

The most accepted model of action for electrical stimulation is that it would induce osteogenesis (Kubota et al., 1995). Similar conclusions were published by Yoshimura et al. (1993), who indicated greater bone formation in periodontal defects treated with guided bone regeneration and biodegradable membranes. It is possible that the difficulty in adapting clinical application systems decreases the study into alveolar bone regeneration through the application of electrical stimuli; Kaynak et al., also indicated a greatest bone formation at sites treated with electrical stimuli. Our descriptive results indicate that electrical stimulus can be a positive influence on bone regeneration, although the model for delivering electricity in this study may alter the final results of this experiment.

It can be concluded that electrical stimulus does not alter the sequence of bone formation in defects generated in rabbit skulls. New studies could reveal the real influence of

SILVA, C.; OLATE, S.; POZZER, L.; MUÑOZ, M.; CANTÍN, M.; URIBE, F. \& DE ALBERGARIA-BARBOSA, J. R. Estimulación eléctrica en la reparación ósea de defectos creados en cráneos de conejos. Int. J. Morphol., 33(3):1146-1150, 2015.

RESUMEN: La estimulación eléctrica ha sido empleada en diferentes condiciones para la regeneración de tejidos. El objetivo de esta investigación es analizar la respuesta tisular de defectos creados en cráneo de conejos a la estimulación eléctrica. Se formaron 2 grupos con 9 conejos de raza New Zealand cada uno; en ellos se realizaron dos defectos de $5 \mathrm{~mm}$, uno en cada parietal, siendo aleatoriamente uno rellenado con el propio hueso autógeno extraído en forma de partículas y el otro mantenido solo con coagulo sanguíneo; se realizó la eutanasia a las 8 semanas y a las 15 semanas para luego estudiar histológicamente las muestras recolectadas. En el análisis de 8 semanas se observó formación ósea en los defectos test y control rellenados con injerto óseo mientras que los defectos con coagulo presentaron un estado muy precoz de formación ósea, observándose abundante tejido conectivo. A las 15 semanas se identificó un estado avanzado de regeneración ósea en los defectos con injerto óseo, donde no se apreció diferencias importantes en los defectos estimulados eléctricamente. Se concluye que el estimulo eléctrico no altera la secuencia de formación ósea; nuevos estudios podrían contribuir a establecer patrones e influencias del estimulo eléctrico en la regeneración ósea.

PALABRAS CLAVE: Estimulo eléctrico; Regeneración ósea; Injerto óseo.

this type of stimuli on bone regeneration.

\section{REFERENCES}

Al-Nawas, B. \& Schiegnitz, E. Augmentation procedures using bone substitute materials or autogenous bone - a systematic review and meta-analysis. Eur. J. Oral Implantol., 7(Suppl. 2):S219-34, 2014.

Buzzá, E.; Olate, S.; Pozzer, L. \& de Albergaria-Barbosa, J. R. Electrotherapy for bone regeneration in dental implants. Int. J. Morphol., 32(2):684-9, 2014

de Oliveira, G. R.; Olate, S.; Cavalieri-Pereira, L.; Pozzer, L.; Asprino, L.; de Moraes, M. \& Albergaría-Barbosa, J. R. Maxillary sinus floor augmentation using blood without graft material. Preliminary results in 10 patients. J. Oral maxillofac. Surg., 71(10):1670-5, 2013.

de Oliveira, M.; Olate, S.; Pozzer, L.; Vásquez, B.; Cantin, M. \& de Albergaría-Barbosa, J. R. Bone repair using calcium sulfate in bone defects of rabbit tibiae. Int. J. Morphol., 32(4):14726, 2014.

Duque Netto, H.; Olate, S.; Klüppel, L.; de Miranda Chaves, M. G. A.; de Oliveira Salgado, I.; Vásquez, B. \& AlbergariaBarbosa, J. Bone regeneration in critical defect treated with bovine inorganic bone matrix with two different carriers. Int. J. Morphol., 31(2):367-72, 2013.

Kaynak, D.; Meffert, R.; Günhan, M. \& Günhan O. A histopathologic investigation on the effects of electrical stimulation on periodontal tissue regeneration in experimental bony defects in dogs. J. Periodontol., 76(12):2194-204, 2005.

Kubota, K.; Yoshimura, N.; Yokota, M.; Fitzsimmons, R. J. \& Wikesjö, M. E. Overview of effects of electrical stimulation on osteogenesis and alveolar bone. $J$. Periodontol., 66(1):2-6, 1995. 
SILVA, C.; OLATE, S.; POZZER, L.; MUÑOZ, M.; CANTÍN, M.; URIBE, F. \& DE ALBERGARIA-BARBOSA, J. R. Electrical stimulation in the bone repair of defects created in rabbit skulls Int. J. Morphol., 33(3):1146-1150, 2015.

Klüppel, L. E.; Antonini, F.; Olate, S.; Nascimento, F. F.; Albergaria-Barbosa, J. R. \& Mazzonetto, R. Bone repair is influenced by different particle sizes of anorganic bovine bone matrix: a histologic and radiographic study in vivo. J. Craniofac. Surg., 24(4):1074-7, 2013.

Netto, H. D.; Olate, S.; Klüppel, L.; do Carmo, A. M.; Vásquez, B. \& Albergaria-Barbosa, J. Histometric analyses of cancellous and cortical interface in autogenous bone grafting. Int. J. Clin. Exp. Pathol., 6(8):1532-7, 2013.

Oishi, M. \& Onesti, S. T. Electrical bone graft stimulation for spinal fusion: a review. Neurosurgery, 47(5):1041$55,2000$.

Olate, S.; de Oliveira, G. R.; Jaimes, M. \& de AlbergariaBarbosa, J. R. Osseous recovery in implant insertion and pre implant reconstructions. Int. J. Morphol., 25(3):64957, 2007.

Tian, N. F.; Wu, Y. S.; Zhang, X. L.; Mao, F. M.; Xu, H. Z. $\&$ Chi, Y. L. Efficacy of electrical stimulation for spinal fusion: a meta-analysis of fusion rate. Spine J., 13(10):1238-43, 2013.

Yoshimura, N. Effects of electrical stimulation on periodontal tissue regeneration in dogs: Application of biodegradable membrane in gtr method. J. Kyushu Dent. Soc.,
47(6):590-606, 1993.

Correspondence to:

Prof. Dr. Sergio Olate

División de Cirugía Oral y Maxilofacial,

Universidad de La Frontera

Claro Solar 115, Oficina 414-A

Temuco

CHILE

Email: sergio.olate@ufrontera.cl

Recibido : 05-03-2015

Aceptado: 18-07-2015 